\title{
Una ruptura en la tradición. La Ciudad Futura y la construcción de una izquierda democrática, 1986-1991
}

\author{
A rupture in tradition. La Ciudad Futura and the building of a \\ democratic left, 1986-1991
}

Ricardo Martínez Mazzola*

\begin{abstract}
Resumen
Este artículo analiza el modo en que, a través de las páginas de la revista La Ciudad Futura, los intelectuales reunidos en el Club de Cultura Socialista releyeron las tradiciones de la izquierda argentina. Aborda su revisión del vínculo entre socialismo y democracia; da cuenta de su crítica a las posiciones de la izquierda revolucionaria; y reconstruye su lectura de la tradición socialista del "viejo" Partido Socialista, lectura que se propone enlazar con la fundación de una "izquierda democrática".
\end{abstract}

Palabras clave: Izquierda argentina, Intelectuales, Socialismo, Democracia, Revolución

\begin{abstract}
This article analyzes the way in which, through the pages of the magazine "La Ciudad Futura", intellectuals gathered in the Club de Cultura Socialista reread the traditions of Argentina left. It discusses the revision of the link between socialism and democracy; it gives an account of their criticism to the positions of the revolutionary left; and reconstructs their reading of the socialist tradition of the "old" Partido Socialista, to which proposses to link with the founding of a "democratic left".
\end{abstract}

Key words: Argentine left, Intelectuals, Socialism, Democracy, Revolution

\footnotetext{
* Argentino, Doctor en historia por la Universidad Nacional de Buenos Aires. Es Investigador Adjunto del CONICET y docente de la Universidad de Buenos Aires y de la Universidad Nacional de San Martín. ricardomm17@yahoo.com
} 
(...) la izquierda sigue pensando la Argentina del '90 como la Argentina del '60, (...) tiene una visión subversivista de una sociedad que ha sufrido grandes traumas, y que hoy como nunca, quiere la consolidación del sistema democrático. O esta izquierda se renueva e introduce toda la nueva temática que está debatiendo la izquierda en el mundo, o está condenada a perecer. No considero que pueda existir un discurso de izquierda socialista si no es a la vez un discurso profundamente democrático. ${ }^{1}$

Al cabo de un largo recorrido - plagado de buenas intenciones y de errores trágicos...- hemos aprendido una lección que no estamos dispuestos a olvidar. Una lección que alguna vez formó parte de la tradición socialista y que hoy queremos redescubrir y recrear al mismo tiempo. El socialismo no puede ser la liquidación de la democracia, sino su plena realización ${ }^{2}$

\section{Introducción}

A mediados de los años 80, al regreso del exilio mexicano, José Aricó y Juan Carlos Portantiero propusieron, junto a otros intelectuales con los que conformaron el Club de Cultura Socialista (CCS), ${ }^{3}$ una reevaluación del vínculo entre socialismo y democracia y, consecuentemente, una relectura de la historia y las tradiciones de la izquierda argentina. Las palabras citadas iluminan el sentido de la apuesta que realizaron en los años '80: renovar las tradiciones de una izquierda argentina a la que consideraban anquilosada. La afirmación de que la democracia era parte constitutiva del socialismo abría a la crítica de las apuestas de la izquierda revolucionaria ${ }^{4}$ y también a la relectura y recuperación de la tradición socialista de comienzos de siglo XX y del "viejo Partido Socialista", relectura que enlazaba con la apuesta por fundar una "izquierda democrática y moderna".

La bibliografía que aborda la actuación de los intelectuales reunidos en el CCS, ha tendido a concentrarse en la vinculación que algunos de ellos establecieron con el gobierno

\footnotetext{
${ }^{1}$ José Aricó, "Tenemos los políticos que nos merecemos", José Aricó Entrevistas 1974-1991, Córdoba, Centro de Estudios Avanzados-Universidad Nacional de Córdoba, 1999, 313-315.

2 "La Ciudad Futura", LCF, $\mathrm{N}^{\circ}$ 1, agosto de 1986, 3.

3 Sobre el Club de Cultura Socialista, véase Ponza, Pablo, "El Club de Cultura Socialista y la gestión Alfonsín: transición a una nueva cultura política plural y democrática", en Nuevo Mundo Mundos Nuevos. Nouveaux mondes mondes nouveaux-Novo Mundo Mundos Novos-New world New worlds (2013) http://nuevomundo.revues.org/65035.

${ }^{4}$ En los años 80 esa crítica se concentraría en la izquierda armada y, como veremos, en el viraje "revolucionario" adoptado por el Partido Comunista argentino en los años '80. Ello se explica porque lo principal de la crítica al peronismo revolucionario, y en particular a la organización "Montoneros", ya había desarrollada evacuada en los años mexicanos en la revista "Controversia". Véase Matías Farías "Un epílogo para los años setenta. Controversia y la crítica a las organizaciones revolucionarias" en Leticia Prislei (dir.) Polémicas intelectuales. Las revistas culturales en el siglo XX, Buenos Aires, Editorial de la Facultad de Filosofía y Letras-UBA, 2015, 355-397.
} 
de Alfonsín, ${ }^{5}$ en la transformación asociada al surgimiento de un nuevo tipo de "intelectual", 6 en las transformaciones que impulsaron en el lenguaje político ${ }^{7}$ o en las transformaciones que impulsaron en la teoría social. ${ }^{8}$ En cambio, el diálogo permanente que mantuvieron con las formaciones de izquierda no ha sido estudiado. ${ }^{9}$ Para empezar a cubrir esa ausencia en este artículo abordaremos las intervenciones a través de las cuales los miembros del CCS, y en particular Aricó y Portantiero, buscaron construir una "frontera" ${ }^{10}$ al interior de la tradición de la izquierda argentina.

Luego de una breve reconstrucción de la trayectoria anterior de estos intelectuales, analizaremos las páginas de La Ciudad Futura (LCF) -revista fundada en 1986 y que hasta bien entrados los '90 se constituiría en el principal espacio de intervención pública de los miembros del CCS-, para dar cuenta de los tres movimientos, asociados pero analíticamente distinguibles, a través de los cuales estos intelectuales construyeron esa frontera. El primero de estos movimientos, al que revisaremos más brevemente por ser el aspecto más trabajado por la bibliografía, refiere a la revisión del vínculo entre socialismo y democracia. El segundo, remite al modo en que interpretaron las apuestas de la izquierda revolucionaria tanto en el pasado argentino como en su propio tiempo, lo que implicó una crítica particularmente asidua y dura a un Partido Comunista (PC) que estaba adoptando una línea "revolucionaria". El tercero se relaciona con la relectura de la historia del viejo Partido Socialista argentino, que había sido duramente criticado tanto desde posiciones

\footnotetext{
${ }^{5}$ Véase Josefina Elizalde, "La participación política de los intelectuales durante la transición democrática: el Grupo Esmeralda y el presidente Alfonsín." Buenos Aires, Temas de Historia Argentina y Americana, 2009.

6 Véase Raúl Burgos. Los Gramscianos argentinos: cultura y política en la experiencia de" Pasado y Presente". Siglo XXI, Buenos Aires, 2004: 71-93; Andrés Tzeiman "Intelectuales y política en Argentina. A propósito del itinerario político-intelectual de Juan Carlos Portantiero" Nuevo Mundo Mundos Nuevos. Nouveaux mondes mondes nouveaux-Novo Mundo Mundos Novos-New world New worlds, 2015.

7 Véase Ariana Reano "Controversia y La Ciudad Futura: democracia y socialismo en debate." Revista mexicana de sociología 74.3, 2012, 487-511; Ariana Reano y Julia Smola. "Palabras políticas. Debates sobre la democracia en la Argentina de los 80" Ediciones Universidad Nacional de General Sarmiento y Universidad Nacional de Avellaneda, Buenos Aires, 2014.

${ }^{8}$ Nora Rabotnikof, "El retorno de la filosofía política. Notas sobre el clima teórico de una década", Revista Mexicana de Sociología, 1992, 4; José Casco "Cultura, modernización y democracia. Max Weber en la obra de los sociólogos intelectuales de la transición a la democracia argentina."Cuadernos de Ciencias Sociales, 2010.

${ }^{9}$ Cecilia Lesgart y Pablo Ponza han abordado las intervenciones de algunos de estos intelectuales y ha planteado interesentes sugerencias sobre su mirada acerca de la historia de la izquierda, pero sus análisis se han concentrado en el período anterior a 1983. Cecilia Lesgart, "El tránsito teórico de la izquierda intelectual en el Cono Sur de América Latina." Revista internacional de filosofía política 16, 2000. 19-41; Pablo Ponza, "La izquierda en su laberinto: intelectuales argentinos, ideas y publicaciones en el exilio (19761983)." Boletín Americanista 60, 2010, 247-262. Podríamos decir, tomando la categoría de Robert Barros que Lesgart utiliza, que la mirada académica se ha ocupado de la "izquierda después de los golpes" pero antes de la transición. Robert Barros, "Izquierda y democracia: debates recientes en América Latina." Zona abierta 39/40, 1986, 27-60.

${ }^{10}$ Como señala Aboy Carlés una frontera política construye una diferencia respecto del pasado, estableciendo una discontinuidad radical con la objetividad materializada en las identidades políticas vigentes. Gerardo Aboy Carlés, Las dos fronteras de la democracia argentina, la reformulación de las identidades políticas de Alfonsín a Menem, Rosario, Homo Sapiens, 2001, 169.
} 
revolucionarias como nacionalistas, y al que recuperaron postulándolo como antecedente para la fundación de una "izquierda democrática". El artículo se cierra con unas breves reflexiones que, luego de situar a la "izquierda democrática" en la larga duración de la historia de la izquierda argentina, se interrogan por algunos de sus puntos ciegos.

\section{El camino a la revisión}

A mediados de 1963 un conjunto de jóvenes comunistas de la ciudad de Córdoba, entre los que se destacaban José Aricó, Oscar del Barco y Héctor Schmucler, publicó el primer número de la revista Pasado y Presente. La revista estrechó el vínculo con un núcleo de estudiantes comunistas de Buenos Aires, encabezado por Juan Carlos Portantiero. Unos y otros fueron expulsados del PC y, más allá de diferencias puntuales, ${ }^{11}$ emprendieron un recorrido político intelectual que se plasmó en las páginas de Pasado y Presente y, luego, en los Cuadernos de Pasado y Presente, pero también en el apoyo a la experiencia guerrillera llevada adelante por el Ejército Guerrillero del Pueblo (EGP) en la provincia de Salta y al sindicalismo clasista cordobés. En su esfuerzo por renovar las tradiciones de la izquierda argentina, estos jóvenes establecieron un diálogo crítico con el maoísmo, el nacionalismo popular y el peronismo. En 1973 la revista Pasado y Presente volvió a publicarse planteando una explícita apuesta por la apuesta por el peronismo revolucionario. ${ }^{12}$ Esas expectativas se vieron defraudadas: lejos de radicalizarse en una dirección socialista, el movimiento peronista experimentó una crisis que dio lugar a un estallido de violencia represiva. La dictadura que puso fin a la experiencia peronista desencadenó una masacre que empujó a miles de argentinos a marchar al exilio.

Entre ellos se hallaban Aricó y Portantiero quienes en México iniciaron una revisión de su bagaje político y doctrinario. El debate colectivo acerca de los errores que habían llevado a la derrota se desplegó en una miríada de debates, artículos en la prensa periódica mexicana, coloquios académicos, pero alcanzó el máximo de concentración en las páginas de Controversia para el examen de la realidad argentina (en adelante Controversia), revista que, bajo la dirección de Jorge Tula, comenzó a publicarse en México en octubre de 1979. En la publicación tomaron la palabra militantes que provenían de la izquierda y el peronismo, los unía el diagnóstico de la derrota de la apuesta revolucionaria y la asunción de que ella no se explicaba sólo por la fuerza del enemigo sino también por los errores de las fuerzas populares. Aunque los ejes de discusión que poblaban las páginas de la revista eran múltiples, había dos que, como señala Farías, ${ }^{13}$ viabilizaban el pasaje del "paradigma

\footnotetext{
${ }^{11}$ A diferencia de los cordobeses de Pasado y Presente el núcleo porteño encabezado por Portantiero emprendería el esfuerzo de organizar una nueva formación de izquierda denominada "Vanguardia Revolucionaria". Sobre Vanguardia Revolucionaria, véase Mora González Canosa, "Un sendero guevarista: Pervivencias y torsiones en los origenes de las 'Fuerzas Armadas Revolucionarias' (1966-1970), Izquierdas, $\mathrm{N}^{\circ} 15$, abril 2013, 56-83.

${ }^{12}$ Respecto al apoyo de Pasado y Presente al peronismo revolucionario, véase Ricardo Martínez Mazzola "Un difícil encuentro. Portantiero y la tradición socialista argentina", Claudia Hilb. (comp.) El político y el científico. Ensayos en homenaje a Juan Carlos Portantiero. Siglo XXI. Buenos Aires, 2009. Págs. 133-168.

${ }^{13}$ Farías, op. cit., 356.
} 
revolucionario" a la "izquierda democrática". El primero era la crítica a un campo revolucionario que, en base a una lectura pobre del entramado civil y político que caracterizaba a los estados del Occidente periférico, entre los que se contaban los países latinoamericanos, había adoptado una visión instrumentalista del Estado. Incapaz de valorar la importancia de la producción de hegemonía, la izquierda había caído en un voluntarismo elitista que había reducido la política al combate entre aparatos militares sin participación de las masas. El segundo eje pasaba por la centralidad de los derechos humanos que, en la lectura de Héctor Schmucler, derivaba no sólo en la reivindicación de la democracia como una dimensión constitutiva, y no instrumental, de un proyecto socialista; sino también en la condena a una izquierda revolucionaria que había adoptado una mirada tecnicista que tomaba a la vida humana como un simple instrumento para la consecución de fines que suponía "trascendentes". 14

A su regreso a la Argentina, Aricó y Portantiero se sumaron al Consejo de Dirección de Punto de Vista, una revista cultural que, bajo la dirección de Beatriz Sarlo, se editaba en Buenos Aires desde 1978. En los días mexicanos los miembros del "Grupo Socialista de discusión" habían establecido vínculos con los editores de esta revista, vínculos que estrecharían al regreso del exilio cuando unos y otros confluyeran para fundar el "Club de Cultura Socialista”. En 1984, la incorporación de Aricó y Portantiero acentuó la dimensión política que Punto de Vista venía esbozando desde 1981. En los números que siguieron a esa incorporación la cuestión de la democracia se reflejó en numerosas intervenciones que, a la vez que destacaban el novedoso papel de una sociedad civil activa, reconocían la difícil relación que la tradición socialista había mantenido con la democracia.

El No 20 de la revista incluía un artículo en el que Portantiero daba cuenta de las difíciles relaciones entre tradición socialista y democracia. Argumentaba que la idea teleológica de una transición hacia el fin del Estado, ligada a la consideración del poder político como una mera emanación de la sociedad, había dificultado la consideración de los mecanismos para equilibrar el poder. Deplorando que los procesos revolucionarios hubieran producido una total concentración del poder en el partido; pero también rechazando los supuestos esencialistas y organicistas que subyacían a las propuestas de "democracia directa", Portantiero reivindicaba la dimensión institucional de la democracia. Para ello tomaba elementos de la tradición liberal, la que había tematizado lo que la tradición socialista tomaba como dato: el control del Estado por la sociedad. El socialismo, declaraba, no podía identificarse con el Estado liberal pero sí rescatar ciertos aportes del liberalismo. En vena poética, y polémica, concluía: “A la teoría política del socialismo le ha sobrado Rousseau y le ha faltado Locke. Por ese exceso y por ese defecto le ha nacido la tentación por Hobbes". 15

\footnotetext{
${ }^{14}$ Ibid., 388.

${ }^{15}$ Juan Carlos Portantiero, "Democracia y socialismo, una relación difícil", Punto de Vista, No 20, mayo de 1984, 5. Las palabras de Portantiero eran provocativas y recibieron respuesta desde la izquierda. El primer número de Cuadernos de Cultura -revista teórica del Partido Comunista, que compartía título con la que dirigiera Héctor Agosti en los años 50- incluía un artículo en el que Abel García Barceló, uno de los principales especialistas del PC en temas de filosofía, quien ya había polemizado con los miembros de Pasado y Presente en los años 60', discutía con quienes, partiendo de que Marx no había desarrollado una teoría del
} 
Pasando al escenario argentino, Carlos Altamirano daba cuenta de las dificultades que las fuerzas socialistas argentinas afrontaban en la nueva hora democrática. Luego de pasar revista a los magros resultados obtenidos por los partidos de izquierda en las elecciones de 1983, analizaba dos publicaciones en las que un dirigente del PC y otro de la "izquierda nacional" pasaban revista a la situación histórica y daban cuenta de las tareas del presente. $\mathrm{Su}$ constatación era desesperanzada "Después del terrible ciclo de los partidos armados, el terrorismo estatal, el belicismo aventurero, la general barbarización de la vida pública, las organizaciones de este sector del mundo político argentino que lograron sobrevivir, proponen las mismas alternativas que una década atrás". ${ }^{16}$

Meses antes, y en un reportaje colectivo realizado por el periódico El Porteño, Portantiero y Aricó planteaban similares consideraciones respecto a la inexistencia de la izquierda como fuerza política relevante. El primero señalaba la necesidad de construir una poderosa fuerza socialista, afirmando que dicha fuerza debía privilegiar "la actividad política en el interior del sistema político y no la guerra como en la década pasada". ${ }^{17} \mathrm{El}$ segundo recordaba que "la presencia de un filón socialista que no va acompañado de una organización acorde" era una constante de la historia argentina. Ello, unido al reconocimiento de elementos transformadores dentro del radicalismo y el peronismo, lo llevaba a subrayar la necesidad de que la izquierda se diera una estructura organizativa moderna que le permitiera "recomponer sus propuestas ideológicas y culturales y su acción transformadora en la realidad".

Partiendo de la consideración de que las propuestas de transformación no pasaban exclusivamente por "las formaciones de la hoy llamada izquierda" sino por "los grandes partidos populares, Aricó subrayaba la necesidad de constituir un área socialista y un polo ideológico y político de nuevo tipo. Era con estos argumentos que fundamentaría la formación del CCS: una organización que se colocaba "explícitamente fuera de la esfera de los partidos políticos y de la izquierda organizada". ${ }^{19}$ En su declaración de principios, y retomando los debates de la izquierda europea particularmente la italiana y la francesa, el

Estado y de la democracia, concluían en la restauración de la visión "burguesa de la democracia". La referencia al texto de Portantiero se hacía explícita en una muy extensa nota final que, luego de resumir los argumentos del sociólogo, concluía postulando la cuestión del pluralismo como la clave de la polémica, a la vez que planteando una pregunta " ¿es posible concebir el período de transición del capitalismo al socialismo sobre la base de una pluralidad que comprenda a los partidos burgueses que persigan el retorno a los antagonismos de clase y a la explotación? Se puede responder con Locke o con Marx." Abel García Barceló, "La crisis del paraíso", Cuadernos de Cultura, Tercera época, №1, otoño de 1985, 54-57.

${ }^{16}$ Carlos Altamirano, "Imágenes de la izquierda", Punto de vista № 21, agosto de 1984, 8. En ese mismo número Beatriz Sarlo manifestaba su perplejidad ante la nostalgia que muchos jóvenes sentían por las certezas de los años 70 y subrayaba que era tarea de su generación el recuperar la memoria, recordando no sólo lo que les habían hecho sino también lo que ellos habían hecho. El planteo abría al señalamiento del modo en que la muerte había sido estetizada en las organizaciones armadas, en particular en Montoneros. Beatriz Sarlo, "Una alucinación dispersa en agonía". Punto de vista No 21, agosto de 1984, 1-4.

17 José Aricó y Juan Carlos Portantiero: "Repensar la democracia”, José Aricó, Entrevistas 1974-1991, Córdoba, Centro de Estudios Avanzados-Universidad Nacional de Córdoba, 1999, 249-250.

${ }^{18}$ Ibid., 250.

19 José Aricó, "Buenos Aires: un espacio para la idea del socialismo”, José Aricó Entrevistas 1974-1991, Córdoba, Centro de Estudios Avanzados-Universidad Nacional de Córdoba, 1999, 262-263. 
Club decía promover una renovación de la cultura de la izquierda que suponía el privilegio de la "cuestión democrática", lo que suponía el abandono de las apuestas insurreccionales, y también la crítica del legado estatalista que, en sus vertientes populistas, leninistas o socialdemócratas, había postulado al Estado como principal instrumento de transformación social. $^{20}$

Cómo recuerda Portantiero, no todos los miembros del CCS compartían el apoyo que un sector- en el que revistaban él, Emilio De Ípola y, en menor medida, Aricó- daba a las políticas del gobierno de Alfonsín. ${ }^{21}$ Dado que entre los que cuestionaban ese acercamiento se destacaba la figura de Beatriz Sarlo, directora de Punto de Vista, Portantiero y Aricó impulsaron la publicación de una nueva revista que, citando a la que publicara Antonio Gramsci hacia fines de la década del 10, se tituló La Ciudad Futura. ${ }^{22}$ Junto a ellos estaba Jorge Tula, viejo compañero de los días de Controversia. Desde el número inaugural se haría visible que la intervención de la revista se estructuraría en torno al concepto de democracia, al que, alejándose de las miradas que lo limitaban a una dimensión instrumental, se proponía revalorizar a la vez que destacar su conexión intrínseca con el socialismo.

\section{La centralidad de la democracia en la identidad de la nueva izquierda}

Pasemos al primero de los tres movimientos de redefinición de la tradición de izquierda que planteamos al comienzo del artículo: el que da cuenta de la centralidad que en esos años alcanza el concepto de democracia. Por tratarse del movimiento más abordado por la bibliografía seremos concisos.

El trazado de una frontera al interior de la tradición de izquierda era ostensible desde el primer editorial de $L C F$ que se abría declarando que, si se quería rescatar al socialismo como proyecto y como movimiento, se debía reconocer su crisis. ${ }^{23}$ Tal señalamiento, se afirmaba, suponía tomar distancia respecto de buena parte de la izquierda argentina que consideraba que renunciar al sueño de una sociedad perfecta y reconocer la pérdida de centralidad de la clase obrera equivalía a "introducir el veneno socialdemócrata". Como guiño y provocación el editorial presentaba a ese demonio con los ropajes del Manifiesto Comunista: frente a él, se señalaba, se santiguaban "la iglesia y los polizontes, los militares

\footnotetext{
${ }^{20}$ La constatación de que la crisis del socialismo no era solo argentina, o siquiera latinoamericana, daba lugar a que la revista publicara asiduamente las intervenciones de intelectuales europeos que indagaban por los nuevos rumbos de la izquierda. Si en el primer número Michel Rocard proclamaba "Atrevámonos a decir que hemos cambiado" (LCF, N¹, agosto de 1986, 9-10) en el segundo Salvatore Veca preguntaba "¿La izquierda no tiene más ideas que éstas?" (LCF, n 2, octubre de 1986, 16-17)

${ }^{21}$ Juan Portantiero, "Juan Carlos Portantiero: un itinerario político-intelectual” (entrevista con Edgardo Mocca)", Buenos Aires, Biblioteca Nacional, 2012, 107-108.

${ }^{22}$ Portantiero y Aricó no dejaron de escribir en Punto de Vista, ni tampoco de formar parte de su Consejo de Dirección, pero su participación en las páginas de la revista disminuyó sensiblemente. Portantiero sólo realizó una breve intervención en homenaje a Leandro Gutiérrez en el № 54. Aricó, en cambio, publicó varios artículos, pero sus intervenciones no se ocuparon de temas políticos de la hora. Aricó continuó como miembro del Consejo de Redacción hasta su muerte en 1991, mientras que Portantiero permaneció en él hasta 1995.

${ }^{23}$ La Ciudad Futura, "La Ciudad Futura", LCF, N¹, agosto de 1986, 3.
} 
cavernícolas del proceso y los gremialistas amnésicos, los fascistas y los comunistas, los intelectuales de izquierda y los de derecha". ${ }^{24}$ Todos ellos, sostenían los editores de la revista, se unían en el deseo del fracaso de la "nueva Argentina" nacida en 1983.

Pese al entusiasmo por esa nueva Argentina, $L C F$ no realizaba una adscripción explícita al alfonsinismo, ni siquiera a la socialdemocracia. Desde el editorial se advertía que no eran socialdemócratas, sino simplemente socialistas que valoraban la posibilidad de construir un sistema político democrático capaz de "arrancar a la República de un funesto destino". El comentario anticipaba varios de los ejes por los que discurriría la prédica de la revista: el enjuiciamiento de ese pasado que parecía marcar un destino oscuro, el papel del sistema político en la transformación de la sociedad, el vínculo entre socialismo y democracia. Era en esta última clave que se argumentaba que trabajar por la construcción de una democracia social no implicaba renunciar a los ideales socialistas sino, por el contrario, "la única forma de ser fiel a ellos". El señalamiento hacía visible el enfrentamiento con una izquierda que leía la "conversión" al credo democrático como renuncia; también abría la posibilidad de revalorizar la tradición del socialismo de comienzos del Siglo XX, el que, según recordaba el editorial, siempre había señalado lo que solo luego de un largo recorrido y muchos errores los miembros de la revista habían redescubierto: "El socialismo no puede ser la liquidación de la democracia, sino su plena expansión."

Era en esa línea de apoyo a la consolidación y expansión a las propuestas reformistas lanzadas por el presidente Raúl Alfonsín, que el primer número de LCF incluía un suplemento en el que Portantiero discutía con quienes consideraban que proyectos como el de la reforma constitucional representaban simples "cortinas de humo" que velaban los verdaderos problemas económicos y sociales. La crítica apuntaba a una izquierda "anacrónica e intelectualmente pre-gramsciana" que, abrazada al dualismo base y superestructura, siempre había considerado a las cuestiones institucionales como derivadas $\mathrm{y}$, por lo tanto, secundarias frente a los temas relacionados con la estructura del poder económico. Tal concepción, señalaba, reaparecía en los discursos que contraponían la "democracia formal", que sería la conseguida hasta el momento, a una "democracia verdadera" entendida en términos de igualdad social. ${ }^{25}$

En una línea similar, y discutiendo tanto con sectores del radicalismo gobernante como con los partidos de izquierda, Aricó subrayaba el carácter impostergable y decisivo de las reformas políticas impulsadas por Alfonsín. A los primeros, que señalaban que lo urgente era defender la situación actual y limitarse al mantenimiento del orden jurídicoinstitucional sin cuestionar sus limitaciones, Aricó respondía que era ilusión creer que se podía consolidar el estado de derecho sin impulsar cambios en la estructura del estado y la sociedad. Retomando la más profunda de las fronteras trazadas por Alfonsín, ${ }^{26}$ Aricó sostenía que existía consenso en reconocer que "la democracia representativa como forma de gobierno de partidos jamás existió en la vida asociada de los argentinos", y que lo que

\footnotetext{
${ }^{24}$ Ibid, p. 3.

${ }^{25}$ Portantiero, Juan Carlos “Una constitución para la democracia”, $L C F$, N¹, agosto de 1986, 17-18.

${ }^{26}$ Frontera que no sólo separaba el presente de la última dictadura militar sino de un largo pasado de faccionalismo, Aboy Carlés, op. cit., 171.
} 
antes había sido considerado como democracia no era más que una forma de gobierno cesarista, en la que la plaza ocultaba la corporativización de los actores sociales. El señalamiento abría a la segunda discusión, la sostenida con las izquierdas que, al incorporar la matriz cesarista de las tradiciones nacional populares, habían abandonado por irrelevantes las preocupaciones acerca del régimen político y el sistema de partidos. Aricó declaraba con dureza que, al creer apoyarse en su maestro para desestimar las formas jurídicas, la cultura de izquierda de raíz marxista había transformado "un principio metodológico como el de base y superestructura en mera tontería". Negando que se pudiera considerar marxistas a concepciones que transformaban la acción política en "un puro acto de violencia, una guerra de aniquilación del adversario", explicaba que si se partía de que "las relaciones sociales de producción y reproducción solo pueden expresarse en las formas que las constituyen", debía concluirse que las "formas jurídicas son las formas mismas del conflicto". Para Aricó el desinterés que mostraba la izquierda respecto a las formas institucionales y jurídicas demostraba que la cultura de la izquierda argentina no estaba instalada en la política sino en la ideología. Afirmaba que, para que el discurso de la izquierda dejara de girar en el vacío, era necesario especificar las instituciones que podían canalizar la participación popular en el presente. El socialismo, concluía Aricó:

(...) debe admitir que ningún protagonismo de masas asegura ni garantiza per se absolutamente nada, que en definitiva la única garantía reside en el carácter organizado o institucional de la democracia porque solo de este modo se puede evitar que una vanguardia, por más iluminada que ésta sea, prevalezca sobre los hombres y establezca el comando y el predominio de una nueva oligarquía. ${ }^{27}$

Hemos citado la intervención de Aricó porque en un solo párrafo reúne varios de los puntos en los que los miembros de la revista fundaban su ruptura en la tradición de la izquierda argentina: la reivindicación de la democracia formal, la crítica de las prácticas vanguardistas y la condena de la experiencia de los socialismos reales. ${ }^{28}$

\section{La crítica a la izquierda revolucionaria}

Decíamos en el apartado anterior que esta izquierda "democrática y moderna" trazó una frontera con un pasado de autoritarismo, en el que se situaba tanto en la izquierda de tradición leninista como de la nacional popular -lo que en muchos casos implicaba la producción de duros juicios respecto a sus experiencias pasadas-. Pero, como es usual, la frontera con el pasado se entrelazaba con el combate con actores del presente a los que se

\footnotetext{
${ }^{27}$ José Aricó, "Una oportunidad de ponernos al día”, LCF, № 2, octubre de 1986, 36.

${ }^{28}$ Los miembros de LCF eran conscientes de que el pasaje que proponían -de una izquierda revolucionaria a una que asumía a la democracia no sólo como terreno ineludible de construcción sino como componente constitutivo del propio orden socialista-, no era algo original y exclusivo del contexto argentino. Así lo declaraban al publicar un extenso artículo en el que Norbert Lechner daba cuenta de la transformación de los proyectos y discursos políticos de la izquierda latinoamericana de su tiempo. Norbert Lechner, "De la revolución a la democracia", LCF, No 2, agosto de 1986, 33-35.
} 
buscaba identificar con ese pasado. Desde LCF estos intelectuales lamentaban que, a diferencia de las europeas y algunas latinoamericanas, la izquierda argentina no estuviera instalada "en el terreno democrático" y continuara viendo a la política como la continuación de la guerra. ${ }^{29}$ Aunque la crítica incluía a la izquierda peronista, y también a sectores que sin provenir del peronismo mantenían cierta concepción politicista y estatalista, $^{30}$ las intervenciones respecto a ella serían en LCF menos frecuentes que en Controversia, siendo en cambio centrales los cuestionamientos a una izquierda "clásica" que seguía abrazada a la idea de "revolución" y aun a la "lucha armada".

Aunque en raras ocasiones sus críticas alcanzaban al Movimiento Al Socialismo, al Partido Obrero y a otros grupos de la izquierda revolucionaria, los intelectuales nucleados en LCF concentraban lo más duro de su crítica en el PC, una fuerza a la que muchos de ellos habían pertenecido y luego abandonado en los años 60'. A mediados de los años '80 esta fuerza estaba experimentando una profunda transformación en su identidad política, adoptando un perfil más revolucionario, latinoamericano y juvenilista. Paradójicamente, este giro, que presentaba importantes puntos de contacto con los postulados de la "nueva izquierda" de la que muchos de ellos habían formado parte, ${ }^{31}$ era el que convertía al PC en uno de los blancos privilegiados de su crítica.

${ }^{29}$ José Aricó “La izquierda y la democracia”, José Aricó, “Entrevistas 1974-1991”, Córdoba, Centro de Estudios Avanzados-Universidad Nacional de Córdoba, 1999, 279.

${ }^{30}$ Buscando trazar un mapa que incluyera a toda la izquierda argentina Emilio De Ípola distinguía entre una izquierda "anacrónica," que defendía una "concepción redencionista y totalizante del socialismo", y una izquierda "moderna" que rechazaba los planteos mesiánicos y la promesa de un futuro paradisíaco. El propio De Ípola reconocía que la contraposición no era muy novedosa, pero el centro de su argumentación se hallaba en la postulación de la existencia de un tercer "tipo" de izquierda al que denominaba "protomoderna". Las diferencias clave entre izquierda "protomoderna" y "moderna" estaban dadas por el lugar que una y otra asignan a la política y el Estado. Mientras la primera, aunque criticaba el mesianismo de la izquierda anacrónica, compartía la "centralidad de la política", la segunda aceptaba los límites de la política; mientras una seguía siendo partidaria de la concentración de las decisiones en el Estado, la otra prefería la promoción de instancias autogestionarias y reivindicaba la esfera de lo público. Trazada la distinción, De Ípola colocaba a las fuerzas de la izquierda argentina en los distintos campos: en la izquierda anacrónica ubicaba al PC y al MAS; en la protomoderna al Partido Intransigente (PI) y al Partido Socialista Popular (PSP); la moderna, de proporciones exiguas, se hallaba en grupos intelectuales, entre los que se contaban los miembros del CCS, y un sector minoritario del Partido Socialista Democrático. Emilio De Ípola, LCF, Nº 11, junio de $1988,3$.

Los argumentos de De Ípola fueron retomados en un editorial que reprochaba a la izquierda el no haber sido capaz de impulsar un programa inteligente de reformas, lo que era asociado con "la resistencia a aceptar al radicalismo como una fuerza de centro, democrática y con posibilidades de formular y aun potenciar proposiciones transformadoras". El texto lamentaba que la izquierda persistiera en las "viejas tradiciones del rechazo y las conspiraciones unilaterales", dividiéndose entre los coqueteos con el peronismo, la búsqueda de frentes electorales basados en programas arcaicos y el intento de extraer de la situación nacional "paradigmas morales" que convocaran a la unidad. Cuestionando por vía elíptica las opciones del Partido Intransigente, la Izquierda Unida - alianza que reunía al PC, al MAS y un conjunto de agrupaciones menores- y la Unidad Socialista, el editorial lamentaba que la izquierda fuera incapaz de desprenderse de su vieja cultura para plantear opciones autónomas y creíbles para el tiempo electoral que se avecinaba. (LCF, $\mathrm{N}^{\mathrm{o}} 13$, noviembre 1988-enero 1989, 13).

${ }^{31}$ Para una caracterización de los rasgos principales de la "nueva izquierda", véase María Cristina Tortti (dir.) La nueva izquierda argentina (1955-1976). Socialismo, peronismo y revolución. Rosario, Prehistoria, 2014.

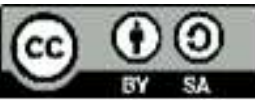


Como señala Casola, un primer síntoma del giro del PC lo constituyó el apoyo que esta fuerza prestó a las candidaturas de Ítalo Lúder y Deolindo Bittel en los comicios presidenciales que en octubre de 1983 marcaron el fin de la dictadura militar. ${ }^{32}$ Lejos de poder ser planteado como un mero acto oportunista, el inédito apoyo a la fórmula peronista puede ser interpretado como el resultado de un primer balance crítico respecto a la actuación del partido en los años de la dictadura; pero también, y en una revisión de más larga duración, como el resultado del predominio en la dirección de sectores que consideraban que los pasados errores del PC derivaban de su excesivo "liberalismo". Así mientras el núcleo de intelectuales que a la vuelta de México crearon el CCS proponía una relectura de la tradición socialista que la emparentaba al liberalismo, el PC experimentaba una transformación de signo opuesto, que lo alejaba de la tradición liberal. ${ }^{33}$ Por otra parte, y como también señala Casola, existía un profundo contraste entre la autocrítica comunista y la que estaban llevando adelante otros partidos e intelectuales de izquierda, mientras estos se centraban en la cuestión de la violencia política, cuyo uso juzgaban duramente, los comunistas cuestionaban su pasado "reformismo." ${ }^{34}$ La distancia, que se acentuó por la diferente valoración que unos y otros planteaban respecto del gobierno de Alfonsín, en particular respecto de su política económica y de derechos humanos, creció al acercarse el $\mathrm{XVI}^{\circ}$ Congreso del PC. En los meses previos al Congreso se hizo visible que, a pesar de fuertes resistencias, la dirección partidaria adoptaría la política de "viraje revolucionario" que, siguiendo las experiencias nicaragüense, salvadoreña y chilena, reclamaba la juventud comunista. $^{35}$

La preocupación con la que los miembros de LCF miraban este proceso se manifestó en los tres artículos que el número inicial de la revista dedicó a abordar las transformaciones del mundo comunista. Mientras el primero de ellos daba cuenta de los debates del XVII ${ }^{\circ}$ Congreso del Partido Comunista Italiano (PCI) realizado meses antes, saludando la flexibilidad de un partido capaz de cambiar; el segundo reconstruía la historia del PC argentino subrayando ciertos rasgos permanentes que, más allá de sus virajes

\footnotetext{
${ }^{32}$ Natalia Casola, El PC argentino y la dictadura militar. Militancia, estrategia política y represión estatal, Buenos Aires, Imago Mundi, 2015, 213.

${ }^{33}$ Así, un documento destinado a fijar líneas para el trabajo cultural destacaba: "Para cumplir un papel renovador la política cultural debe asumir la herencia cultural nacional y latinoamericana, aspecto al que los comunistas argentinos llegamos con el tren atrasado. Para eso necesitamos liberarnos del 'peso muerto' de la tradición liberal en nuestras concepciones de la cultura...". Partido Comunista "La política cultural del Partido Comunista", 5 (Disponible en "Fondo Fernando Nadra", Centro de Documentación e Investigación de la Cultura de Izquierdas en Argentina (CEDINCI), Buenos Aires).

${ }^{34}$ Ibid., 216.

${ }^{35} \mathrm{La}$ gran importancia de la revolución nicaragüense y el papel "mítico" de la "Brigada del café" en la transformación de la identidad de los comunistas argentinos ha sido destacado por Paula Fernández Hellmund "El Movimiento de Brigadistas Libertador General San Martín y el XVI Congreso del Partido Comunista de la Argentina. Tradición y frontera política", presentada al IX Encuentro Nacional y III Congreso Internacional de Historia Oral de la República Argentina "Los usos de la Memoria y la Historia Oral", 2009, (disponible en http://www.historiaoralargentina.org/attachments/article/eho2009/Memoriaymilitancia/Fern\%C3\%A1ndezPaula.pdf). En cambio, y a pesar de los numerosos estudios que abordan la transformación "revolucionaria" que en esos años experimentaba el PC chileno, no existen trabajos que indaguen si esa transformación impactó en el PC argentino.
} 
superficiales, persistían: la "autorepresentación de la clase", el descreimiento en la vía democrática, la delegación de los representantes autodesignados, la delegación en algún país extranjero del liderazgo revolucionario. ${ }^{36}$

El vínculo entre ambas intervenciones era hecho explícito por un breve artículo en el que, luego de subrayar el contraste entre el PCI y el PC argentino, Aricó daba cuenta de los sorprendentes cambios que en esos días experimentaba éste último. Luego de décadas de inmovilismo, señalaba, algo estaba ocurriendo. Sin embargo, el tono del viejo militante comunista no era celebratorio: lamentaba que el fastidio por la actitud del PC ante la dictadura militar hubiera derivado en "un debate que no presagia un rumbo favorable para la consolidación democrática ni al avance de las fuerzas del socialismo". Aricó lamentaba que el "extremismo ciego y aventurero de los supuestos renovadores y el oportunismo a ras del suelo de los viejos dirigentes" cerraran la posibilidad de elaboración teórica capaz de indagar las razones de la cerrazón del Partido. Pero Aricó estaba lejos de ver en los debates comunistas un camino que simplemente llevaba a la insignificancia, por el contrario manifestaba su temor de que la ausencia de conciencia democrática y un discurso plebeyizado produjeran el retroceso a momentos superados de la historia del comunismo. Luego de recurrir a un recurso extremo, el emparentar la posición de los comunistas argentinos con la de los alemanes de comienzos de los '30, Aricó concluía su intervención declarando su temor por la orientación de un partido que quiere convertirse en "un activo factor de erosión del sistema". ${ }^{37}$

Meses después Aricó retomaba la crítica al plantear, en un reportaje publicado en el diario cordobés La voz del interior, que el PC argentino se diferenciaba tanto del italiano, dispuesto a recomponer sus definiciones políticas para adecuarlas a los nuevos tiempos, como del PC francés, sumido en el inmovilismo. El PC argentino, reconocía Aricó, estaba modificando sus postulados de décadas, pero lo hacía para regresar:

(...) al peor tipo de formulaciones estratégicas. Y digo del peor tipo porque corresponde a etapas muy primarias del movimiento socialista y comunista mundial: la idea de clase contra clase, de insurrección armada, de ruptura violenta del poder; la subestimación de las formas democráticas de una sociedad, el cuestionamiento de la legitimidad de un gobierno elegido por la mayoría del pueblo (...),38

Aricó explicaba que, situado ante la necesidad de actualizarse, el PC respondía retrocediendo. Se trataba de un anacronismo que, advertía, podía ser peligroso ya que, en una situación de estabilidad precaria como la que atravesaba la Argentina, las soluciones de fuerza que proponía podían favorecer los proyectos golpistas. ${ }^{39}$

Los artículos publicados en LCF suscitaron respuestas. El No 3 de la revista- incluía dos cartas que discutían algunas de las afirmaciones de Aricó. Por un lado Américo Tatián,

\footnotetext{
${ }^{36}$ Sergio Rodríguez, "El error de un acierto", LCF, No 1, agosto de 1986, 13.

${ }^{37}$ José Aricó, "Otro congreso, otro estilo", LCF, N 1, agosto de 1986, 13.

38 José Aricó "El socialismo como una aventura del pensamiento", José Aricó “Entrevistas 1974-1991, Córdoba, Centro de Estudios Avanzados-Universidad Nacional de Córdoba, 1999, 272.

39 Idem.
} 
antiguo militante del PC cordobés, le cuestionaba el no prestar suficiente atención a la influencia, e incluso dominio, que sobre las posiciones del PC argentino ejercía el PC de la Unión Soviética. Por otro lado, el intelectual comunista Claudio Pérez discutía con la lectura que Aricó hacía del $16^{\circ}$ Congreso, con su caracterización del PC como “crepuscular", y con su denuncia de que proponía "erosionar" el sistema democrático. ${ }^{40}$

La intervención de Tatián no suscitó respuesta por parte de LCF; la de Pérez, en cambio, mereció una muy extensa contestación por parte de Aricó. Escribiendo pocas semanas después de que el XVI Congreso del PC aprobara el "viraje revolucionario", 41 explicó que su desconfianza se apoyaba no solo en la historia del PC sino en el camino que estaba siguiendo para salir de su crisis: la adopción de una posición "objetivamente erosionadora del sistema democrático". Aricó argumentaba que la derrota, "ipor unanimidad, una vez más!", del último sobreviviente de la vieja guardia, Rubens Íscaro, arrastraba consigo la política comunista estructurada hacia 1945; pero, dejando ver que su rechazo por la nueva línea aun más duro que el que sentía por la vieja, concluía: "Es toda la concepción de la revolución democrático burguesa la que ha sido aventada a golpes de revolucionarismo verbal, de consignas exasperadas e intemperantes". ${ }^{42}$

Recordando que el XVI Congreso no se había ocupado ni de la crisis del modelo soviético, ni de la quiebra del estado social, ni de la consumación del estado populista, Aricó señaló que la ausencia de estos problemas, centrales en la discusión de las corrientes críticas del movimiento socialista internacional, evidenciaba el "tozudo anclaje en el pasado" del PC argentino que postulaba que la ausencia de contacto con la realidad se superaba "voluntad revolucionaria". El cordobés diagnosticaba que el PC constituía "casi una secta cobijada en algunos ámbitos universitarios" que ya no se colocaba como interlocutor de las grandes formaciones políticas argentinas sino que emulaba a "los grupúsculos de extrema izquierda" en ver quién podía mostrarse "más violento y ultrancista contra el gobierno democrático y contra el orden político". 43

La intervención de Aricó abriría a dos vías de indagación. La primera planteaba una relectura de la historia del PC argentino; ${ }^{44}$ la segunda, proponía debatir la cuestión de la lucha armada y la violencia política. En la Argentina de mediados de los años '80 no había sectores que lleven a adelante acciones armadas. Por ello el debate sobre las mismas remite

${ }^{40}$ Claudio Pérez, "Erosionar el sistema capitalista, no el sistema democrático", LCF, № 3, diciembre de 1986, 10.

${ }^{41}$ Sobre el XVI ${ }^{\circ}$ Congreso del PC, véase Casola, op. cit., 215-224

42 José Aricó, “¿Recreación o consumación del comunismo argentino?”, LCF, № 3, diciembre de 1986, 9.

${ }^{43}$ Idem.

${ }^{44}$ Esta línea estuvo muy presente en los primeros números de LCF. En el $3^{\circ}$ se publicó el intercambio entre el escritor Roberto Arlt, "compañero de ruta" del PC y Rodolfo Ghioldi y la dirección del periódico comunista Bandera Roja. Más allá del interés erudito, la publicación del debate permitía trazar, en forma oblicua, un paralelo entre la línea "'sectaria", "obrerista" y "anti-intelectual" que, en consonancia con las posiciones definidas por el VI Congreso de la Tercera Internacional, el PCA había adoptado a fines de los años '20 y el "viraje" realizado por el mismo partido en su XVI Congreso. Esta línea de indagación sería retomada en dos intervenciones acerca de la política adoptada por el PC argentino en los años '30: realizadas por Aricó, quien de todos modos rescataba ciertos aspectos de aquel giro "obrerista", y María Caldelari, e incluidas en el Dossier "La Argentina en los años '30”, publicado en el número $4^{\circ}$ de LCF. 
a lo que estaba sucediendo en otros países o, más frecuentemente, a la crítica de las experiencias del pasado argentino.

Con respecto a las experiencias de lucha armada en otros países latinoamericanos la principal preocupación de los miembros de la revista remitía al caso chileno. Así mientras las consideraciones sobre la experiencia nicaragüense eran relativamente positivas, su mirada respecto del giro que había adoptado el Partido Comunista Chileno a partir de la "Política de Rebelión Popular de Masas" y de la creación del "Frente Patriótico Manuel Rodríguez" era impiadosa. ${ }^{45}$ El número 2 de LCF se abría con un editorial que daba cuenta de las disyuntivas que enfrentaba la oposición a la dictadura de Pinochet. Luego de celebrar la firma de un documento multipartidario en el que un amplio espectro de fuerzas opositoras fijaban "las bases para una salida pacífica y urgente hacia la democracia y el establecimiento de objetivos mínimos a cumplir durante el período de transición", 46 LCF lamentaba que tal acuerdo hubiera pasado inadvertido por producirse un día después del atentado a Pinochet por parte del Frente Patriótico Manuel Rodríguez. El editorial el acto evaluaba que el acto había tenido efectos contradictorios: por un lado, su grado de justeza permitía suponer cierta complicidad con esferas próximas al poder, lo que implicaría la existencia de fracturas en el poder militar; por otro, la violencia represiva con que el régimen había respondido al hecho podía hacer aflorar el miedo, "el más efectivo de los elementos desmovilizadores". Remitiendo a las evaluaciones sobre la experiencia argentina de los '70 LCF advertía acerca de la riesgosa tentación de delegar en las "organizaciones armadas de resistencia" una respuesta que debía provenir del pueblo y sus instituciones políticas y sociales. $^{47}$

Pero mientras las críticas a las apuestas de los partidos de la izquierda argentina, y también de la chilena, se hacían en el terreno del debate político y en la forma de discusión teórica, la evaluación de los usos de la violencia y la lucha armada en el pasado argentino dejaba de lado la interrogación por sus fundamentos sociales y sus consecuencias políticas para adoptar un tono de simple condena, articulada en términos morales. El juicio moral, ya presente en algunas de las intervenciones que LCF publicó con ocasión del $20^{\circ}$ aniversario de la muerte de Ernesto "Che" Guevara, ${ }^{48}$ alcanzó su punto más profundo, y doloroso, en la

\footnotetext{
45 Sobre las transformaciones del PC chileno y el surgimiento del "Frente Patriótico Manuel Rodríguez", véase Rolando Álvarez Vallejos. "Los 'hermanos rodriguistas'. La división del Frente Patriótico Manuel Rodríguez y el surgimiento de una nueva cultura política en la izquierda chilena, 1975-1987”, Izquierdas, $\mathrm{N}^{\mathrm{o}} 3,2009$.

${ }^{46}$ LCF, ¿Violencia armada o desobediencia civil?” LCF, №2, octubre de 1986, 3.

${ }^{47}$ La revista dejaba ver su temor por la posibilidad de una guerra civil en una sociedad a la que la dictadura de Pinochet había dividido en dos. Evaluaba también que la situación chilena reforzaba el corporativismo de las Fuerzas Armadas de la región: en Argentina las abroquelaba en la oposición a una Ley de Defensa que limitaba sus funciones, en Uruguay les permitía empujar al Poder Ejecutivo a "defender una absurda pretensión de dejar impunes crímenes y saqueos". (Idem)

48 El Número 7 de la revista incluía dos artículos de Portantiero y Aricó que combinaban un emocionado recuerdo de la figura del "Che" y un duro juicio sobre un legado en el que destacaban "su sed de absoluto". Aun más dura era la evaluación trazada en un artículo publicado en el número siguiente de LCF en el que Sergio Bufano recordaba su lectura del famoso párrafo en el que Guevara, luego de lanzar la consigna de crear muchos Vietnam, daba bienvenida a la muerte si esta hacía que otros tomaran su lugar en la batalla. Bufano subrayaba, quizás asignando demasiada responsabilidad al Che, que los jóvenes que habían escuchado
}

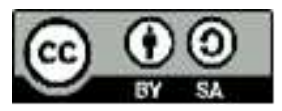


intervención de Héctor Schmucler. ${ }^{49}$ Schmucler tematizaba la cuestión de la violencia, lamentando que poco se la debatiera en la Argentina de los '80. Para tratarla retomaba la figura de Rodolfo Walsh, subrayando que su carácter de militante montonero había sido borrado. Las palabras de Schmucler no se orientaban, como sucedería con otras posteriores, a la reivindicación de ese carácter sino al señalamiento de que ese borramiento llevaba a la incomprensión del sentido de las acciones de quienes pensaban estar librando una guerra. Los guerrilleros, afirmaba, habían compartido con sus represores la creencia en la fuerza liquidadora de las armas ante la cual el otro no merecía ninguna consideración. Schmucler lo probaba con una serie de citas de la organización Montoneros, a la que él y su hijo habían pertenecido. La última, de Mario Firmenich, rezaba: "Nosotros hacemos de la organización un arma [...] y, por lo tanto, sacrificamos la organización en el combate a cambio del prestigio político, tenemos cinco mil cuadros menos, pero ¿cuántas masas más? Este es el detalle."50

A Schmucler no le interesaba evaluar si la apreciación era correcta en lo referente a la influencia de masas de Montoneros, sino subrayar lo estremecedor de un juicio que consideraba a los 5000 muertos como un simple instrumento. ${ }^{51} \mathrm{La}$ instrumentalidad, subrayaba, se fundaba en la certeza de un futuro que justificaba los sacrificios actuales. El planteo, explicaba, se emparentaba con las utopías modernas, el capitalismo y el socialismo, que imaginando construir la totalidad habían hundido sus raíces en el nihilismo. Argumentaba que, aunque los militantes habían buscado acabar con la injusticia y la humillación, las revoluciones solo habían contribuido a sembrar el desasosiego.

el llamado de esa figura legendaria ya no podían convertirse en sencillos ciudadanos sino que se veían convocados a sumarse a su lucha por la segunda independencia. Lamentaba que, después de la muerte de Guevara, los "Ches" se hubieran multiplicado para morir, muchos de ellos en combate o en oscuras salas de tortura. La muerte había sido, tal y como proclamaba Guevara, "la novia de todos". Sobre las intervenciones en ocasión del $20^{\circ}$ aniversario del "Che", véase Ricardo Martínez Mazzola, "Una revista para la "izquierda democrática". La Ciudad Futura (1986-1989)", en Leticia Prislei (dir.) Polémicas intelectuales, debates políticos. Revistas culturales en el siglo XX, Editorial de la Facultad de Filosofía y Letras, Universidad de Buenos Aires, 399-436.

${ }^{49}$ Schmucler, Héctor, "Miedo y confusión”, La Ciudad Futura Nº 10, abril de 1988, 12-13.

${ }^{50}$ Idem.

${ }^{51}$ El artículo de Schmucler presentaba un claro contraste con otro publicado en el mismo número 10 de LCF, en el que el antropólogo peruano Manuel Jesús Granados analizaba la ideología, el modelo organizativo, la ritualidad y la base social de "Sendero Luminoso". Negando la posible eficacia de las prácticas contrainsurgentes aplicadas contra ese movimiento considerando, el investigador evaluaba que, más allá de la pérdida de militantes, las mismas no hacían más que aumentar el apoyo social al grupo guerrillero. Y lo resumía con una "frase popular": "el PCP SL metió aguja (300) militantes, y ha sacado barreta (serán incontables, a no dudarlo)" (Manuel Jesús Granados, "El PCP Sendero Luminoso: aproximaciones a su ideología, LCF, $\mathrm{N}^{\circ} 10$, abril de 1988, 31). Si la frase que rescataba Granados tenía una resonancia muy cercana a las palabras de Firmenich que citara Schmucler - "¿Tenemos cinco mil cuadros menos, pero ¿cuántas masas más? Esto es el detalle”-; el registro de los artículos era muy contrastante. Mientras Granados mantenía un tono ascéptico que le permitía valorar positivamente la "ganancia" política del intercambio propuesto; Schmucler, padre de un militante montonero desaparecido y él mismo ex-militante de la organización, apelaba a la cita para rechazar la "racionalidad instrumental" con que las organizaciones revolucionarias habían dispuesto de la vida de sus miembros.

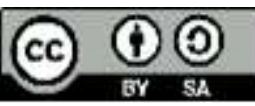


Antes de cerrar el artículo Schmucler volvía a adoptar un tono personal, recordando la última vez que había visto a su hijo. Relataba que había intentado convencerlo de que abandonara el camino que lo llevaba a una muerte inútil, pero que Pablo había preferido la fidelidad a sus compañeros. Ante ello, y trazando un paralelo con la figura de Cristo, se interrogaba por la propia responsabilidad en que su hijo creyera no tener familia y sacrificara su vida por su organización. El final remitía al futuro, imaginando que cuando las preguntas superaran la confusión, los miedos ya no paralizarían y se podría "saber que hay bien y que hay mal. Que no todos somos culpables de todo, pero que ninguno es inocente."

La toma de distancia respecto a la práctica de las organizaciones armadas alcanzará su paroxismo a comienzos de 1989, momento en que la apuesta por la violencia revolucionaria hizo una breve aparición en la escena política argentina. El 23 de enero de 1989, un grupo de militantes del Movimiento Todos por la Patria (MTP), tomó el cuartel del Regimiento III del Ejército Argentino, situado en la localidad de Tablada, muy cercana a la Ciudad de Buenos Aires. El MTP esperaba que el copamiento, que se realizaba en oposición a un supuesto intento de golpe de estado que estarían a punto de llevar adelante sectores de las Fuerzas Armadas, suscitara una gran movilización de apoyo por parte de la población de la zona. ${ }^{53}$ Pero tal movilización no se produjo, y sí un ataque del ejército que reconquistó el cuartel, dejando de unos treinta muertos y varios desaparecidos en las filas del MTP y once entre los militares. $^{54}$

El copamiento mereció la condena de buena parte de la dirigencia política argentina, condena que también se expresó en las páginas de LCF. El número 15, publicado en el mes de marzo, incluía varias intervenciones, todas ellas muy críticas, sobre la toma. Luego de denunciar que el "ataque terrorista" alimentaba la prédica antidemocrática y la caza de brujas, Portantiero subrayó que el hecho no debía rechazarse solo por sus consecuencias políticas sino que era necesario condenar todo uso de la violencia para dirimir conflictos políticos, especialmente en democracia. ${ }^{55} \mathrm{El}$ director de LCF lamentaba que, como buena parte de la sociedad argentina, las formaciones políticas de la izquierda no hubieran profundizado en su reevaluación del pasado, limitándose a juzgar el uso de la violencia solo en términos de error metodológico. Frente a ello, y anteponiendo las evaluaciones morales a las políticas, concluía: "quienes coparon La Tablada son asesinos, no compañeros

\footnotetext{
52 Ibid., p. 13.

${ }^{53}$ Sobre el copamiento del cuartel de La Tablada véase Claudia Hilb, "La Tablada: el último acto de la guerrilla setentista", en Lucha Armada en Argentina, № 9, 2007, 4-22. Sobre la ideología del MTP y su particular lectura de la "cuestión democrática", véase Vera Carnovale, "De Entre Todos a La Tablada. Redefiniciones y permanencias del ideario setentista", Polhis, Año 6, No 12, segundo semestre de 2013, 244264.

${ }^{54}$ Hasta hoy no hay acuerdo en el número de muertos y desaparecidos que dejó la intervención del ejército. Tampoco está claro cuantos murieron en enfrentamientos y cuántos sufrieron ejecuciones extrajudiciales. La muy poco transparente actuación de la justicia argentina en la investigación de los hechos ha merecido la elevación de pedidos de informes a la Corte Interamericana de Derechos Humanos.

${ }^{55}$ Juan Carlos Portantiero, "La distancia entre la política y el terror", LCF, No 15, febrero-marzo de $1989,6$.
} 
equivocados...mi diferencia respecto de ellos es tan absoluta que o bien la izquierda no es lo que ellos dicen o yo no soy de izquierda." 56

La voz colectiva de la revista, expresada a través de un editorial, profundizaba en el análisis. Además de declarar la "condena total y sin reservas" al ataque al cuartel, trazaba una frontera, de un lado estaban quienes defendían la democracia, los derechos humanos y la no violencia, del otro quienes cuestionaban esos principios. La frontera, que cruzaba todos los alineamientos partidarios y tradiciones ideológicas, también dividía a la izquierda separando a la democrática de quienes llevaban acciones terroristas, pero también de quienes las "alimentaban." $\mathrm{El}$ argumento no se dirigía solo a un MTP ya diezmado sino también a otros grupos que mantenían una hipótesis revolucionaria que impedía valorar la democracia. Así lo hacía visible Aricó quién, en una intervención publicada en ese mismo número de La Ciudad Futura, argumentaba que era la escasa influencia política de las fuerzas de izquierda la que las llevaba a soñar con el salto a un futuro revolucionario. Citaba como ejemplo a un PC que a partir de su XVI Congreso había adoptado un discurso populista y apuntado todos sus cañones contra el gobierno radical. Retomando los comentarios planteados tiempo atrás en los que dejaba ver la desconfianza por el giro guerrillerista del PC, Aricó denunciaba que ese partido, aun sin dar un apoyo explícito a la acción del MTP, no la había condenado. ${ }^{58}$

A mediados de 1989, luego de los sucesos de La Tablada y del inicio de la hiperinflación, las ilusiones que los miembros de $L C F$ habían depositado en la apuesta reformista de Alfonsín aparecían defraudadas. Para buscar las razones de esa frustración el número $16^{\circ}$ de la revista incluía un suplemente titulado "Los bloqueos de la reforma". Al artículo inicial, en el que Aricó sindicaba a radicales y peronistas como principales responsables del agotamiento del impulso transformador, ${ }^{59}$ seguía otro en el que Portantiero planteaba una evaluación, también negativa, de las posiciones de la izquierda en la transición democrática. ${ }^{60}$ Explicaba que las muchas formaciones de izquierda compartían una minusvaloración de la democracia política a la que consideraban puramente formal. Citando como prueba la vacilación que habían mostrado las fuerzas progresistas ante el "asalto al cuartel de la Tablada", Portantiero manifestaba la esperanza de que, ante la reaparición del espectro guerrillero, se produjera la ansiada división ideológica que trazara la frontera entre las fuerzas de izquierda que valoraban la democracia política y aquellas que mantenían el "jacobinismo de las vanguardias armadas que actuaban en nombre del pueblo". 61

\footnotetext{
56 Idem.

${ }^{57}$ LCF, "Esta pelea también es la nuestra", LCF, No 15, febrero-marzo de 1989, 3-4.

58 José Aricó, “Contra la lógica de la guerra”, LCF No 15, febrero-marzo de 1989, 7.

59 José Aricó, "Los bloqueos de la reforma", LCF N 16, abril-mayo de 1989, 9.

60 Juan Carlos Portantiero, "La transición democrática y la izquierda política", LCF, № 16, abril-mayo de 1989, 9-10.

61 Ibid., p. 10.
} 


\section{La invención de una tradición. Entre Juan B. Justo y el nuevo PS}

Un año después de salir a la calle, LCF publicó un breve texto a modo de balance. El mismo señalaba que las vicisitudes experimentadas en ese lapso confirmaban que "la estabilidad democrática y la justicia social requieren de la presencia de una fuerza socialista moderna". Era por ello, se subrayaba a continuación, que la revista proponía entablar un "debate sobre la izquierda" orientado a crear el clima adecuado para gestar esa "fuerza socialista". 62

El anterior comentario permite señalar un cambio en la prédica de LCF. Si bien desde el comienzo la revista había subrayado su definición "socialista", hasta el momento no había hecho énfasis en la necesidad de construir una "fuerza socialista". Ello comenzaría a cambiar en 1987 cuando -luego del alzamiento militar de Semana Santa, y en paralelo con cierto debilitamiento de las ilusiones depositadas en el gobierno de Alfonsín, ${ }^{63}$ - se empezó a producir tanto una rescate de la tradición del viejo PS, como un acercamiento entre algunos de los intelectuales del Club Socialista y dirigentes políticos de los partidos de la Unidad Socialista.

En realidad, el proceso de rescate de la tradición socialista se había iniciado tiempo antes, ${ }^{64}$ pero había sido puesto entre paréntesis por la apuesta en la canalización de las energías reformistas en el alfonsinismo. A poco de la crisis de Semana Santa LCF acentuaría su interés por la izquierda argentina y sus tradiciones. Así lo hacía ver el número 6 de la revista que al tiempo que convocaba al "debate sobre la izquierda"- abriendo con ese título una sección fija que se mantendría a lo largo de muchos números-, publicaba un suplemento sobre "Gramsci en América Latina" en el que Portantiero destacaba los momentos históricos puntuales en los que los socialistas latinoamericanos habían avanzado en la elaboración de un proyecto hegemónico. Entre esos momentos, junto a la tradición obrerista del comunismo chileno inaugurada por Recabarren y la obra teórica de Mariátegui, Portantiero ubicaba al "de Juan B. Justo y la tradición del Partido Socialista en

\footnotetext{
${ }^{62}$ LCF, “A un año del comienzo”, LCF, No7, octubre de 1987, 2.

${ }^{63}$ Ese debilitamiento no implicaba necesariamente la ruptura del vínculo con el líder radical, vínculo que, al menos en el caso de Portantiero y Emilio De Ípola, se mantendría aún después de 1989. Sin embargo, si se seguía defendiendo a un gobierno acosado, ya no se pensaba que él consumaba y superaba las tradiciones políticas argentinas que lo precedían.

${ }^{64}$ En marzo de 1982, cuando aun se hallaba en el exilio mexicano, Portantiero había publicado un artículo en la revista Punto de Vista en el que, luego de presentar a la Argentina del ' 900 como una sociedad con un fuerte componente inmigratorio en la que los extranjeros -lo que en buena parte equivalía a decir los obrerosestaban excluidos de la vida política, argumentaba que era ese duro contexto el que había llevado a los socialistas argentinos a concentrar sus propuestas en la edificación de un sistema político que expresara a las nuevas fuerzas sociales, incorporando al inmigrante a la práctica ciudadana. Para ello, explicaba, habían establecido extensas redes de socialización orientadas a los trabajadores, que incluían partido, sindicatos, bibliotecas y cooperativas. Portantiero rescataba la "notable (...)capacidad organizativa de los socialistas por penetrar en la cultura popular", pero lamentaba que estas iniciativas se hubieran visto limitadas por una concepción pedagógica de la política que, al despreciar "los resortes emocionales, maniqueos, de la comunicación", no pudo plantear más que un mensaje elitista. Juan Carlos Portantiero, "Nación y democracia en la Argentina del novecientos", Punto de Vista, No 14, marzo de 1982, 3-6.
} 
la Argentina, hasta comienzos de la década del cuarenta". 65 La propuesta de Justo, consideraba, habría planteado "el nivel más profundo de articulación entre la Segunda Internacional y un país de América Latina". Sin embargo, reconocía Portantiero, su esfuerzo había sido vencido por la convocatoria de los populismos, y para dar cuenta de los motivos de esa derrota Portantiero volvía sobre los argumentos planteados en el artículo de Punto de Vista: Justo se habría enfrentado con el obstáculo que fijaba la "construcción desde arriba" de la sociedad, característica propia de la Argentina y el resto de los países latinoamericanos. Para desarrollar un verdadero espíritu antiestatalista, necesario para avanzar en la imposición de reformas "desde abajo", Justo había apelado a una tarea pedagógica orientada a desbaratar el "mito popular" que veía al Estado como constituyente y que se expresaba en la tradición del caudillismo. Portantiero explicaba que "el mundo presuntamente contrahegemónico del justismo era un mundo de cooperativas, de bibliotecas [...] que debían contener en sí todas las posibilidades liberadoras de una sociedad laica frente al Estado" formidable, evaluaba que ese modo de pensar la relación entre política y masas no había permitido organizar una verdadera voluntad nacional-popular. Trabado como estaba en una "concepción iluminista del socialismo", Justo no había podido construir un lenguaje capaz de asimilar a las masas subalternas argentinas que estaban inmersas en un complejo "proceso de estratificación social y cultural" ligado a un acelerado crecimiento económico y a "la inestabilidad de los valores culturales provocada por la difusión de patrones europeos sobre un terreno recién y sólo parcialmente despegado del siglo XIX hispano criollo". 67

Si Portantiero rescataba elementos de la apuesta de Justo, no dejaba de subrayar sus limitaciones. Una operación similar, aunque de mayor aliento y erudición, fue la que planteó Aricó con su libro"la hipótesis de Justo", 68 el que, aunque sólo sería editado en forma completa en 1999, iría viendo la luz en formato de artículos publicados a lo largo de los años '80.

Discutiendo con las miradas que pensaban al médico argentino como un mero imitador del socialismo europeo, Aricó destacaba su intento de adaptar el socialismo a las condiciones nacionales y la historia argentina. Reconocía que Justo compartía con las elites la idea de una sociedad argentina lábil y fértil para las apuestas proyectivas, pero destacaba que se diferenciaba de ellas por basar la realización de sus proyectos en un sujeto social nuevo: el proletariado. Aricó señalaba que Justo había percibido que en la sociedad argentina, aunque formalmente republicana, los sectores populares estaban excluidos de la escena política. Por ello, explicaba, la lucha de clases no solo debía orientarse solamente a obtener mejoras en las condiciones de vida, sino a imponer el sufragio universal. Pero el vínculo entre lucha económica y lucha política, la toma de consciencia del proletario de su explotación como trabajador y como ciudadano, no era inmediata, sino que se alcanzaba a

\footnotetext{
${ }^{65}$ Juan Carlos Portantiero, "Gramsci en clave latinoamericana”, LCF, No7, agosto de 1987, 12-13.

66 Íbid, 13.

${ }^{67}$ Idem.

${ }^{68}$ José Aricó, La hipótesis de Justo. Escritos sobre el socialismo en América Latina. Buenos Aires, Sudamericana, 1999.
} 
través de la construcción de las propias instituciones populares. Y Aricó celebraba aquí el fuerte societalismo del planteo de Justo: "la emancipación del proletariado no consiste...en un mero acto de conquista del poder por el Partido Socialista... sino en un proceso de lucha social en el que la clase aprende a organizarse y gobernar una sociedad nueva." $" 99$

Aricó consideraba que la "hipótesis de Justo" contenía propuestas orientadas a posibilitar que la clase obrera deviniera decisiva en la sociedad argentina. Ello llevaba a la pregunta por las limitaciones que habían hecho naufragar tal posibilidad. Era la ausencia de una perspectiva de poder, explicaba, lo que había llevado al PS a plantear la lucha obrera como acción defensiva. De este modo, la autonomía de la clase obrera había devenido en aislamiento corporativo lo que llevó a la incomprensión del vínculo entre el proletariado y el resto de los sectores populares en la formación social argentina, vedando una correcta comprensión del radicalismo yrigoyenista. ${ }^{70}$ Aricó señalaba que el modo de abordar el vínculo entre desarrollo económico y proceso democratizador, y su "feroz repulsión ante el desorden y la desobediencia", habían conducido a que Justo privilegiara exageradamente el papel del partido obrero como "racionalizador de la insubordinación social". 71 Adoptando un modelo de correspondencia entre modernización capitalista y socialismo, Justo no habría visto que no era el atraso sino la modernidad capitalista la que explicaba la morfología concreta de la formación de las clases populares. Así Aricó encontraba el límite último de la hipótesis de Justo en un sobredimensionamiento del grado de homogeneidad capitalista de la formación social argentina y la virginidad política de las clases populares". ${ }^{72}$ Ello habría llevado a que Justo simplificara la lucha de clases, considerando que si la modernidad de la sociedad argentina no había derivado en la adopción de posiciones socialistas por parte de los trabajadores, ello representaba un simple problema de atraso cultural, que podía ser superado con una constante labor de educación socialista.

Como podemos ver, el rescate que Aricó y Portantiero hacían de la figura de Justo y la tradición del viejo PS no estaba exento de críticas. Su mirada respecto del proceso de reunificación iniciado por el Partido Socialista Popular y el Partido Socialista Democrático - dos fuerzas que, a pesar tener orígenes muy distintos, ${ }^{73}$ habían confluido en la Unidad

${ }^{69}$ Ibid., 86.

${ }^{70}$ Ibid., 94.

${ }^{71}$ Ibid., 108.

${ }^{72}$ Ibid., 120.

${ }^{73}$ El PSD surgió de la división del PS en 1958. De él tomaban parte los sectores más conservadores, antiperonistas y anticomunistas del viejo partido, encabezados por Américo Ghioldi. Luego de la muerte de éste a comienzos de los años ' 80 , y en buena parte gracias al ingreso de un sector de militantes socialistas provenientes de la Confederación Socialista Argentina, entre los que se contaban Alfredo Bravo y Héctor Polino, el PSD había relegado sus rasgos más conservadores y antidemocráticos. El PSP, por su parte, había nacido de la fusión de un sector del Partido Socialista Argentino - el otro brazo nacido de la ruptura del PS en 1958- con grupos de militantes universitarios reunidos en el Movimiento Nacional Reformista. A lo largo de los años '80 el PSP iría abandonando los componentes más populistas y nacionalistas de su cultura política, a la vez que combinando la vieja estructura celular por un modelo más tradicional de organización territorial. Sobre las rupturas del PS, véase María Cristina Tortti: El "viejo" partido socialista y los orígenes de la "nueva" izquierda (1955-1965), Prometeo, Buenos Aires, 2009. sobre las transformaciones del PSD y PSP, véase Fernando Suárez: «El socialismo y los desafíos de la democratización», en A. R. Lazzeretti y F. M. 
Socialista (US) y proponían la refundación de un PS unificado- era aun menos positiva. Un ejemplo lo encontramos en las críticas que Aricó hacía al documento "Democracia y Socialismo" aprobado por el PSP a comienzos de 1987. Aricó comenzaba señalando que la crisis del discurso nacional, popular, antiimperialista y revolucionario, el que por décadas había ocluido las apelaciones de la izquierda, abría una oportunidad para la refundación del socialismo. Sin embargo, advertía, para que esta recreación fuera exitosa, el socialismo debía mostrarse capaz de aglutinar "en un gran archipiélago de organizaciones autónomas, a todas las fuerzas de cambio de la sociedad". 74

A fines de 1989, el triunfo de la US en Rosario, la tercera ciudad del país, permitía a Aricó augurar que el socialismo abandonaba su "vida letárgica" para intentar ocupar un lugar mayor en el escenario argentino. ${ }^{75}$ Pero la celebración del triunfo rosarino no cerraba la pregunta acerca de si el nuevo PS era capaz de abrirse más allá del PSP y el PSD. Al respecto Aricó reclamaba que los debates acerca de una eventual unificación no fueran tratados "como un asunto interno de las organizaciones que conforman la Unidad Socialista, sino como un hecho particular que interesa a todos los socialistas, y en particular a los que con La Ciudad Futura contribuimos al logro de este mismo propósito". 76 Para concluir, Aricó planteaba dos problemas: uno de ellos remitía a la compatibilidad entre las tradiciones políticas encarnadas en el PSP y el PSD ${ }^{77}$ el otro al modo de atraer a los miles de socialistas dispersos. Al respecto le parecía insuficiente el llamado genérico a sumarse a las fuerzas existentes considerando que era necesario formar sus propios organismos clubes, ateneos, periódicos - de modo de ser capaces de tomar en sus manos "la gran tarea de organizar un partido socialista nuevo". ${ }^{7879}$

Suárez (coords): Socialismo y democracia, Editorial de la Universidad Nacional de Mar Del Plata, Mar del Plata, Abril de 2015

74 José Aricó, "Imaginar hoy el socialismo en la Argentina", LCF, № 8-9, diciembre de 1987, 10.

La apuesta por la construcción de un espacio socialista amplio que fuera más allá de los partidos identificados con la tradición se colaba incluso en el homenaje que LCF brindó a Justo con motivo del sexagésimo aniversario de su fallecimiento. En la contratapa del número 10 de la revista un breve texto nacido de la pluma de Aricó destacaba al socialista como un político que bregó por superar el interés mezquino de facción, como un intelectual que buscó dejar atrás "la mentalidad de tribu que caracterizaba a la función política argentina". José Aricó. "Juan B. Justo: un ejemplo de integridad moral", LCF, № 10, abril de 1988, 32.

75 José Aricó, “¿Unidad Socialista o unidad de los socialistas?”, LCF, no 20, diciembre de 1989- enero de 1990,7 .

${ }^{76}$ Idem.

${ }^{77}$ Aricó subrayaba que, más allá del acuerdo en ciertas generalidades, ambos partidos tenían profundas diferencias en la forma de apreciar la crisis argentina y sus modos de resolución. "Si unos creen remontarla al modelo de crecimiento que se conformó a fines del siglo pasado, los otros la definen como la desintegración de un modo de vinculación entre capitalismo y estado y capitalismo y masas que iniciado en la década del '30 encontró en el peronismo una forma política hegemónica que ya no puede funcionar. Si el discurso de unos no oculta su tinte nacionalista y hasta a veces patriotero, el de los otros no parece haberse desprendido íntegramente de una tradición clasista y anacrónica." Ibid., 8.

${ }^{78}$ Ibid.

${ }^{79}$ Aun más radical era el llamado a la renovación socialista que lanzaba Sarlo en el número 21 de LCF. Allí argumentaba que el menemismo, al desarmar las viejas certezas nacional-populistas y levantar las banderas del individualismo liberal, había abierto la posibilidad de un discurso socialista que superara las "formas primitivas del antiestatalismo" prevaleciente. Pero, advertía, para ello se debía aceptar "que no existe una 
La combinación entre el rescate de la tradición socialista y la crítica a las fuerzas que estaban llevando adelante el proceso de reunificación del PS se repetía en la reseña que Aricó dedicaba a un libro que la historiadora Marta Bonaudo escribiera sobre el líder demócrata progresista Lisandro de la Torre. El modo en que la autora presentaba éste como un dirigente de colorido "casi radical-socialista"- llevaba a la pregunta por las razones de que el encuentro entre socialistas y demócratas progresistas no se hubiera producido antes de los '30. Aricó reconocía que en parte ello se debía al esquematismo de Justo, pero asignaba un rol mayor a la reivindicación de la soledad del santafesino, a quien le había faltado lo que sí tuvo Justo: "la conciencia de la necesidad de organizar a las masas

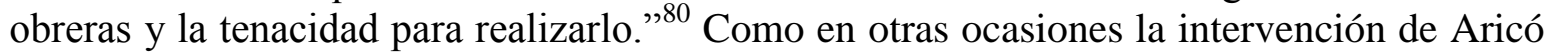
miraba al presente: el rescate de la voluntad de construcción de Justo y la condena al solipsismo de de la Torre no planteaban un mero juicio histórico sino una crítica a los dirigentes políticos de la hora. Así lo hacían ver sus palabras finales:

Su tragedia, por más personal que ésta fuera, no deja de proyectar una curiosa luz sobre la evolución política de nuestra nación y sobre las limitaciones de sus hombres más avanzados. Buenos en ideas y en intenciones pero incapaces de llevarlas a cabo. Como si entre nosotros solo hubiera lugar para los demagogos e inescrupulosos. Y así nos va. ${ }^{81}$

José Aricó falleció en agosto de 1991. El número 29 de LCF incluyó la reproducción de un texto que Aricó había publicado en La Vanguardia con motivo del $95^{\circ}$ aniversario del PS. Las consideraciones del cordobés no eran concesivas: en el casi centenario órgano de prensa socialista, planteaba que aunque era necesario fundar un partido socialista, éste no podía surgir de la renovación y ampliación del anterior, sino que debía ser una creación ex novo que apelara a tradiciones y fuerzas políticas que trascendieran al campo estrecho en que el PS había llevado adelante su labor. La tradición socialista se había consumado y no podía ser reconstituida en los viejos términos ya que, consideraba, el partido fundado por Justo "dejó de tener una funcionalidad hace muchos años y lo que resta de él es más una herencia del pasado que una fuerza con espíritu innovador y gravitación en la renovación de la cultura política nacional”. ${ }^{2}$ Planteado esto Aricó se preguntaba "¿qué contribuciones puede dar el viejo PS a la fundación de uno nuevo?”. Respondía, muchas, y las enumeraba. Pero se preguntaba también en qué medida estaba dispuesto a realizar esas contribuciones; sus dudas hacían blanco en "la falta de una real y efectiva voluntad política" en su

tradición socialista viva en la Argentina" y que recomponer una tradición socialista implicaba reconocer que "los temas del nacional populismo y de la revolución habían ocupado, hasta hacerlo desaparecer casi por completo, el espacio potencial del socialismo". El ideal socialista debía ser restaurado y renovado de modo que el socialismo fuera como era en sus comienzos "el partido de lo nuevo". Era a partir de considerar que lo recuperable de la tradición socialista era la relación con lo nuevo, y no una sustancia, que Sarlo postulaba que la refundación del socialismo supondría "nuevos modos de organizar la experiencia y la práctica, ...una reforma de las identidades políticas, ...una nueva cultura" (Beatriz Sarlo, "Un desafío socialista, LCF, No 21, febrero-marzo de 1990, 7)

${ }^{80}$ José Aricó, “Límites de la inteligencia”, LCF, № 27, febrero-marzo de 1991, 28.

${ }^{81}$ Idem.

${ }^{82}$ José Aricó, "Un debate amplio y desprejuiciado", LCF, № 29, junio-septiembre de 1991, 6. 
dirigencia, que no se decidía a abrir las filas socialistas a los jóvenes ni a incorporar a intelectuales de filiación socialista. ${ }^{83}$

\section{Conclusiones}

En "La cola del diablo", su trabajo acerca de la recepción del pensamiento de Antonio Gramsci en América Latina, Aricó dio cuenta de cómo los golpes de Estado que asolaron la región y las consiguientes experiencias de exilios tuvieron un "efecto corrosivo" sobre las certidumbres de la izquierda desmitificando "el espejismo revolucionario" y haciendo estallar el "marxismo dogmatizado de los sesenta". ${ }^{84}$ En esa situación, recuerda, Gramsci había dejado de ser visto como el "corrector" del pensamiento leninista para convertirse en componente decisivo para la renovación de la cultura política de la "izquierda socialista" de modo de volverla capaz de tomar en cuenta "las experiencias, tradiciones y luchas concretas de una pluralidad de sujetos para los cuales tienen una significación concreta los ideales de igualdad y de justicia que defiende el socialismo". 85

La interpretación de Aricó no era individual e idiosincrática sino que formaba parte de un viraje emprendido por buena parte de la izquierda argentina. Podemos decir que, en términos generales, en los años 80 sectores de la izquierda argentina experimentaron un giro similar, pero casi inverso, al que habían sufrido a fines de los años '50. Como señala Altamirano, ${ }^{86}$ si hasta la caída del peronismo las fuerzas que componían la izquierda argentina se habían presentado como el ala avanzada de un "campo democrático y progresista", después de 1955 la izquierda habían pasado a pensarse como parte de un "campo nacional" estructurado en torno al concepto de "imperialismo". Era en esa clave, que había reemplazado al prisma liberal-democrático, que el peronismo ya no era leído como un movimiento autoritario, y aun totalitario, sino como un movimiento de liberación nacional. ${ }^{87}$ Simétricamente, a comienzos de los '80 se produjo nueva ruptura en la historia de la izquierda argentina; surgió así nueva izquierda más preocupada por la democracia y las libertades que por la "cuestión nacional", y que colocó el centro de su mirada no en el Estado sino en "la sociedad". Quizás fue por su rechazo de los rasgos de la izquierda nacionalista y estatizante que la había precedido, que esta "nueva izquierda", en cuyas filas revistaban intelectuales como Aricó y Portantiero, fue capaz de recuperar el legado societalista de Juan B. Justo y el "viejo" socialismo argentino.

De todos modos, y como vimos en el apartado anterior, ese rescate de la historia del viejo socialismo argentino no estaba exento de críticas, e incluso del señalamiento de que la tradición estaba muerta y que para producir una nueva era necesario salir de los marcos estrechos que surgían de la refundación del PS socialista tal y como era encarnada por los

\footnotetext{
${ }^{83}$ Ibid., 7.

${ }^{84}$ José Aricó, “La cola del diablo. Itinerario de Gramsci en América Latina”, Buenos Aires, Puntosur, 1988, 113-114.

${ }^{85}$ Ibid., 115.

${ }^{86}$ Carlos Altamirano, "Peronismo y cultura de izquierda en la Argentina (1955-1965)", Carlos Altamirano, Peronismo y cultura de izquierda, Buenos Aires, Siglo XXI, 2011, 96.
} 
equipos dirigentes del PSP y el PSD. La ambivalente relación que estos intelectuales mantuvieron con las fuerzas que estaban emprendiendo la reactivación de la tradición socialista argentina deja ver que la construcción de una herencia de socialismo democrático y societalista, y la definición de los límites respecto de otro "autoritario" - la izquierda armada y revolucionaria-, no eran acompañadas de una definición clara respecto del espacio en torno al cual esa "izquierda democrática y moderna" pudiera reunirse y homogeneizarse. Esta ausencia puede asociarse con el fuerte vínculo que los intelectuales ligados al Club Socialista desarrollaron con líderes fuera del espacio de la izquierda -como el radical Alfonsín, el demócrata cristiano Carlos Auyero y el peronista Carlos "Chacho" Álvarez-; con la inserción en el mundo intelectual de los '80, en el que el pluralismo constituía el valor principal; y también con el hecho de que la aceptación de los cuestionamientos a la forma partido no había sido acompañada de la propuesta de formas alternativas de articulación política.

Sin embargo, consideramos que el problema más profundo remite a la definición del sujeto político en nombre del cual se proponía la acción política transformadora: la forma "pueblo" deconstruída en vena crítica, no había sido reemplazada por la identificación de un nuevo sujeto transformador, un despojado al que levantar, de un amenazado al que defender. Si algún sujeto ocupaba el lugar central en sus discursos era la ciudadanía democrática, lo que llevaba a una defensa genérica de la democracia en la que el socialismo se diluía. ${ }^{88}$ En términos del sociólogo Juan Carlos Torre, él mismo un viejo compañero de ruta de Aricó y Portantiero en Pasado y Presente, lo que la "nueva izquierda" democrática proponía no era una "izquierda social", que asociara sus posiciones a un sujeto histórico como los trabajadores, sino una "izquierda moral", definida por la opción por valores como la igualdad y la justicia. ${ }^{89}$ Quizás fuera por esta falta de vinculación con sectores sociales concretos la que hizo que, como reconoció Aricó, la renovación cultural iniciada en los años del exilio, de fuerte impacto en el ámbito intelectual, no encontrara eco en los partidos de izquierda ni en los movimientos sociales que, entrados los años '90, lideraron la resistencia a la transformación neoliberal impulsada por el gobierno de Carlos Menem.

Recibido: 31 diciembre 2015 Aceptado: 6 marzo 2016

\footnotetext{
${ }^{88}$ El reemplazo de la referencia al pueblo por la ciudadanía, marca otro punto de contacto con el viejo PS, aunque menos con el conducido por Justo que con el que en los años '30, y en el marco de la filosofía antipositivista de Alejandro Korn, emprendió un "giro ético" que luego, y bajo el liderazgo de Américo Ghioldi, se acentuaría luego en el enfrentamiento al peronismo. Véase Ricardo Martínez Mazzola, "Justo, Korn, Ghioldi. El Partido Socialista y la tradición liberal”, Papeles de Trabajo, N8, Noviembre 2011, 35-52. 89 Juan Carlos Torre: «Comentarios a la ponencia de Carlos Altamirano», Prismas. Revista de historia intelectual, $\mathrm{N}^{\circ} 1,1997,154-155$.
} 


\section{Bibliografía}

-Aboy Carlés, Gerardo, Las dos fronteras de la democracia argentina, la reformulación de las identidades políticas de Alfonsín a Menem, Rosario, Homo Sapiens, 2001, 169.

-Águila, Gabriela, "El Partido Comunista argentino entre la dictadura y la transición democrática", Revista de Historia Actual, No 6, 2010

-Altamirano, Carlos, Peronismo y cultura de izquierda, Buenos Aires, Siglo XXI, 2011.

-Álvarez Vallejos, Rolando "Los 'hermanos rodriguistas'. La división del Frente Patriótico Manuel Rodríguez y el surgimiento de una nueva cultura política en la izquierda chilena, 1975-1987", Izquierdas, N³, 2009.

-Aricó, José, "La cola del diablo. Itinerario de Gramsci en América Latina", Buenos Aires, Puntosur, 1988, 113-114

-Aricó, José, La hipótesis de Justo. Escritos sobre el socialismo en América Latina. Buenos Aires, Sudamericana, 1999.

-Aricó, José, Entrevistas 1974-1991, Córdoba, Centro de Estudios Avanzados-Universidad Nacional de Córdoba, 1999,

-Barros, Robert, "Izquierda y democracia: debates recientes en América Latina”, Zona Abierta, 3940, abril-septiembre de 1986, 27-60.

-Barros, Sebastián, Orden, democracia y estabilidad. Discurso y política en la Argentina entre 1996 y 1991. Córdoba, Alción, 2002.

-Burgos, Raúl, Los gramscianos argentinos. Cultura y política en la experiencia de Pasado y Presente, Buenos Aires, Siglo XXI, 2004.

-Casco, José "Cultura, modernización y democracia. Max Weber en la obra de los sociólogos intelectuales de la transición a la democracia argentina."Cuadernos de Ciencias Sociales, 2010.

-Casola, Natalia, El PC argentino y la dictadura militar. Militancia, estrategia política y represión estatal, Buenos Aires, Imago Mundi, 2015.

-Cortés, Martín, Un nuevo marxismo para América Latina. José Aricó: traductor, editor, intelectual. Buenos Aires, Siglo XXI, 2015

-De Diego, José Luis, ¿Quién de nosotros escribirá el Facundo? Intelectuales y escritores en Argentina (1970-1986), La Plata, Ediciones al margen , 2007.

- Elizalde, Josefina. "La participación política de los intelectuales durante la transición democrática: el Grupo Esmeralda y el presidente Alfonsín." Temas de Historia Argentina y Americana, vol. 15. 2009.

- Farías, Matías, "Un epílogo para los años setenta. Controversia y la crítica a las organizaciones revolucionarias" en Leticia Prislei (dir.) Polémicas intelectuales. Las revistas culturales en el siglo XX, Buenos Aires, Editorial de la Facultad de Filosofía y Letras-UBA, 2015, 355-397.

-González Canosa, Mora, "Un sendero guevarista: Pervivencias y torsiones en los origenes de las 'Fuerzas Armadas Revolucionarias' (1966-1970), Izquierdas, № 15, abril 2013, 56-83.

-Lesgart, Cecilia "El tránsito teórico de la izquierda intelectual en el Cono Sur de América Latina." Revista internacional de filosofía política 16, 2000. 19-41.

-Lesgart, Cecilia, Los usos de la transición a la democracia. Ensayo, ciencia y política en la década del '80. Rosario, Homo Sapiens, 2003

-Martínez Mazzola, Ricardo, "Un difícil encuentro. Portantiero y la tradición socialista argentina", en Claudia Hilb. (comp.) El político y el científico. Ensayos en homenaje a Juan Carlos Portantiero. Siglo XXI. Buenos Aires, 2009. Págs. 133-168. 
-Martínez Mazzola, Ricardo, "Justo, Korn, Ghioldi. El Partido Socialista y la tradición liberal”, Papeles de Trabajo, $\mathrm{N}^{\circ} 8$, Noviembre 2011, 35-52.

-Martínez Mazzola, Ricardo "Una revista para la 'izquierda democrática'. La Ciudad Futura (19861989)”, en Leticia Prislei (dir.) Polémicas intelectuales, debates políticos. Revistas culturales en el siglo XX, Editorial de la Facultad de Filosofía y Letras, Universidad de Buenos Aires, 2015, 399436.

-Nun, José y Juan Carlos Portantiero, Ensayos sobre la producción democrática en la Argentina, Buenos Aires, Puntosur, 1987.

-Paramio, Ludolfo, Tras el diluvio. La izquierda ante el fin de siglo. Madrid, Siglo XXI, 1988.

- Ponza, Pablo, "El Club de Cultura Socialista y la gestión Alfonsín: transición a una nueva cultura política plural y democrática", en Nuevo Mundo Mundos Nuevos. Nouveaux mondes mondes nouveaux-Novo Mundo Mundos Novos-New world New worlds, 2013, http://nuevomundo.revues.org/65035

-Ponza, Pablo, "La izquierda en su laberinto: intelectuales argentinos, ideas y publicaciones en el exilio (1976-1983)." Boletín Americanista 60, 2010, 247-262.

-Portantiero, Juan Carlos, La producción de un orden. Ensayos sobre la democracia entre el estado y la sociedad, Buenos Aires, Nueva Visión, 1988.

-Portantiero, Juan Carlos, El tiempo de la política. Construcción de mayorías en la evolución de la democracia argentina. Buenos Aires, Temas, 2000.

-Przeworski, Adam, "Ama a incerteza e serás democrático", Novos Estudos, No 9, julio de 1984.

-Rabotnikof, Nora, "El retorno de la filosofía política. Notas sobre el clima teórico de una década", Revista Mexicana de Sociología, 1992, 4

-Reano, Ariana, "Controversia y La Ciudad Futura: democracia y socialismo en debate." Revista mexicana de sociología, vol. 74, no 3, 2012, 487-511.

-Reano Ariana y Julia Smola. "Palabras políticas. Debates sobre la democracia en la Argentina de los 80" "Ediciones Universidad Nacional de General Sarmiento y Universidad Nacional de Avellaneda, Buenos Aires, 2014

-Torre, Juan Carlos, «Comentarios a la ponencia de Carlos Altamirano», Prismas. Revista de historia intelectual, $\mathrm{N} .{ }^{\circ} 1,1997,154-155$

-Tortti, María Cristina (dir.), La nueva izquierda argentina (1955-1976). Socialismo, peronismo y revolución. Rosario, Prehistoria, 2014.

-Tzeiman, Andrés: "Intelectuales y política en Argentina. A propósito del itinerario políticointelectual de Juan Carlos Portantiero" Nuevo Mundo Mundos Nuevos. Nouveaux mondes mondes nouveaux-Novo Mundo Mundos Novos-New world New worlds, 2015

Publicaciones periódicas

-Controversia para el análisis de la realidad argentina, México D.F., 1979-1981.

-Cuadernos de Cultura (Tercera época), Buenos Aires, 1985-1986.

-Punto de Vista. Revista de Cultura. Buenos Aires, 1978-1991.

-La Ciudad Futura. Revista de Cultura Socialista. Buenos Aires, 1986-1991 